\title{
The Theosophy dr. K.R.T. Radjiman Wediodiningrat Towards Civic Intelligence
}

\author{
Rani Melina Deasy ${ }^{1}$, Hermanu Joebagio ${ }^{2}$, Susanto $^{3}$. \\ \{1ranimelina@student.uns.ac.id, ${ }^{2}$ hermanujoebagio@staff.uns.ac.id, ${ }^{3}$ susantofibuns@staff.uns.ac.id \} \\ 1,2,3 Sebelas Maret University, Indonesia
}

\begin{abstract}
Civic Intelligence can be a control tool for the creation of a harmonious national and State life. Indonesia's diversity conditions are a challenge for the realization of a society that has civic intelligence. Therefore, this research aims to learn the life journey of dr. K.R.T Radjiman Wediodiningrat and the importance of his thought that effects the foundation of Indonesia State. This research used the historical research method, consists of 1. Heuristic, 2. Source criticism, 3. Interpretation, 4. Historiography. The research result shows that dr. K.R.T Radjiman Wediodiningrat was a philosopher and cultural practitioner that hold a significantly important role in the establishment of the foundation of Indonesia State. Farther, the theosophy movement became one of the changes that supported and strengthened the national movement spirit for dr. K.R.T Radjiman Wediodiningrat. The strength in the character of and become K.R.T Radjiman Wediodiningrat was able to inspire, how civic intelligence grows, and become the strength in establishing the identity of Indonesia State every time. In summary, the form and the result of dr. K.R.T Radjiman Wediodiningrat's thought was to create an Indonesian society that was humanitarian and had civic intelligence.
\end{abstract}

Keywords: Civic Intelligence, dr. K.R.T. Radjiman Wediodiningrat, Humanity, Theosophy

\section{Introduction}

Civic Intelligence can be defined as the capacity of groups of various sizes to deal with challenges together effectively[1]. The purpose of civic intelligence is to form good citizens in the rational dimension and also in the spiritual, emotional and social aspects to be able to solve various social problems over the times. Civic intelligence is the capacity of collectivities from small informal groups to humanity as a whole to equitably and effectively address critical shared issues[2]. Public intelligence is one of the essential achievements for young people with character. Four essential components must be fulfilled so that someone is declared to have civic intelligence, namely intellectual intelligence, spiritual intelligence, emotional intelligence and moral intelligence[3]. However, the conditions faced by the Indonesian people at this time do not show the ideal conditions, the weak character of the nation indicates this, this is evidenced by the emergence of various kinds of conflicts from the unwise use of social media, then disputes between religious adherents, selfishness and the rise of cases of 
intolerance[4]. Examples of cases of inter-religious conflict in Ambon, although declared to have ended to date feelings of mutual suspicion still occur[5]. Then the number of cases of fraud and the spread of fake news on social media[6]. Fake news or hoax may not be a new problem anymore in Indonesia but also a global problem. Diversity in Indonesia makes it a conflict-prone country if its people are weak in filtering information. Besides fake news moral issues such as examples of violence committed by a student to his teacher becomes a sad phenomenon [7]

History of learning is one of the essential tools in realizing civic intelligence. Learning history not only discusses events but can also be in the form of analysis of the heroic values of biographies of national figures. For example, dr.K.R.T. Radjiman Wediodiningrat is one of the nation's figures who has contributed significantly to Indonesia's independence efforts. Radjiman gained theosophy knowledge for the first time when he served in Semarang, starting with his introduction to a prospective teacher named R. Prawiraharja, who at that time became his patient[8]. Radjiman's attraction in Western philosophy brought Radjiman's interest in studying theosophy. His meeting with an adherent of theosophy, Mr Hinlopen Laberton made Radjiman even more convinced to explore theosophy, even then he voluntarily joined to be part of the theosophical members. Radjiman began to deepen and make theosophy as a fill-in his inner emptiness. During the period of dr.K.R.T., Radjiman Wediodiningrat became chairman of the Boedi Oetomo theosophy had a significant influence; this was evidenced by a large number of Boedi Oetomo members who were members of the theosophical movement. Besides Radjiman, there are many of the Indonesian national movement who are members of theosophical, as mentioned by Iskandar P. Nugraha namely Soekarno, Mohammad Yamin, Mohammad Hatta, Achmad Subardjo, Agus Salim, Musso and others. Soekarno, as one of the national figures, claimed that what pushed him into the philosophy and thought of theosophy was because he often visited the theosophical library in Surabaya. Sukarno got access to the library from his father (R. Soekemi) who was a member of theosophy[9].

Theosophy was transformed into a social movement namely Theosophical Society (Theosophical Society) which was founded in 1875 in New York, the United States pioneered by Helena Petrovna Blavatsky (a Russian aristocrat), and Henry Steel Olcott (a lawyer and veteran of the United States civil war). The establishment of this movement was motivated by concerns about the clash of religions and science in the 19th century, especially Darwin's materialistic theory of evolution[9]. In 1883, it was estimated that the Pekalongan movement for the first time was founded in Indonesia, pioneered by a European aristocrat named Baron van Tengnagel. During the Dutch colonial period, the Theosophical Society was known as the Netherlands Indische Theosofische Vereniging (NITV)[10]. The Purpose of Theosophy Association:

1. Holding the core of brotherhood among human beings regardless of nation, creed, gender, caste or colour.

2. Advancing lessons comparing religion, philosophy and knowledge.

3. Investigating unexplained natural laws and hidden human forces.

Agree with the aim of the theosophical gathering dr.K.R.T. Radjiman Wediodiningrat and the leaders of the Indonesian movement assumed that the theosophical change was cultural and humanist, it was considered to be following the conditions of the Indonesian people who were struggling to oppose colonialism. This research is relevant because, in conventional Indonesian historical writing, theosophy becomes a different theme that can even be called a puzzle that is missing from the frame (history of Indonesia), and also its contribution in the formation of civic intelligence is not widely known by many people. Through discussion of 
the theosophical thinking of dr.K.R.T. Radjiman Wediodiningrat can be seen how the process of the formation of civic intelligence and its contribution to social and State life.

\section{Research Method}

Based on this background, this study used historical research methods. The method of historical research is the process of evaluating and analyzing the records of the past critically, then reconstructed based on data or findings which are then obtained from historiography or historical discussion [11]. The ancient method consists of four steps: Heuristic (collecting data), Source Criticism (internal criticism and external criticism of the source to be used), Interpretation (interpretation), and Historiography (searching history). The choice used by the author is to discuss psychology, where the writer analyses the background of the main character who is questioned by various factors, especially the environment, the existence inspirator and also has his own.

\section{Results And Discussion}

\subsection{Radjiman's Life journey to Wediodiningrat}

Radjiman played an essential role in establishing the foundation of the Indonesian State with his involvement in the BPUPK and PPKI courts and his actions in Boedi Oetomo organization in voicing nationalism. Radjiman is the son of a male corporal named Sutadrana. His father is a descendant of Bugis, while his mother is a descendant of Manado[8]. Radjiman was born on April 21, 1879, in the village of Mlati, Glondongan[12]. Radjiman's family's economic condition almost made Radjiman unable to continue school, but thanks to the help of dr. Wahidin Soedirohoesodo. Besides, from being a foster father, Dr Wahidin Soedirohoesodo also played an essential role in Radjiman's life as his inspiration. As stated by Adler that humans are motivated by social impulse, he believes that human consciousness is a powerful component in determining choices and creating life goals[13]. Radjiman's character building and thinking were heavily influenced by dr. Wahidin Soedirohoesodo. Radjiman learned about life such as patience, wisdom, patient and careful.

The profession as a doctor in ancient times was just like obtaining an academic degree from the Netherlands, and it did not affect the low social status of the owner. Javanese prijajis, especially prijajis who worked in government, thought that the medical profession as a lowclass profession, even more, it was often valued as labour[14]. The number of OSVIA schools was higher than STOVIA because indeed at that time, the orientation of the prijajis was to be a government employee. OSVIA schools existed in several regions: Bandung, Magelang, Probolinggo, Serang, Madiun, Blitar and in Bukittinggi (West Sumatra)[15]. While there was only one STOVIA, in Batavia. The emergence of the movement in Indonesia was originated from STOVIA students who had the same background and had the same fate (living in suffering due to colonialism and not getting recognition because of low social status). The Boedi Oetomo organization became a suitable organization and became existed in the future as a youth movement organization at that time. Boedi Oetomo successfully became the originator of the birth of the "Youth Pledge". The people who joined Boedi Oetomo organization not only had the vision to unite the nation but also carried out the goal towards a 
humane society, this was demonstrated through its existence in an effort to advance education for the natives by emphasizing the learning of nationalism to their students.

His journey to being a Javanese doctor was not easily obtained. Radjiman's primary education was Tweede Europese School (Dutch Low School). Then he continued his education to Tweede Europese Lagere School (E.L.S.). Although in poor conditions because his family's economic status did not break the spirit of Radjiman. He became a diligent and diligent figure. At the age of 14, he succeeded in completing his school at E.L.S., and he got a recommendation to proceed to the Javanese Doctors school. Even though his father's condition could no longer afford Radjiman's school, in the end, Radjiman continued to continue school with financial support from dr. Wahidin Soedirohoesodo who turned out to have a kinship with the Radjiman family. Turning to the age of 20 years, Radjiman successfully completed his schooling with a Javanese Doctor degree with very satisfying grades and was included in one of the outstanding students. Thus, Radjiman was given priority to be directly appointed as an employee of the Dutch Governor with as an assistant surgeon at the Weltevreden hospital in Betawi [12], [16] Other sources state that his career began in 1899 as a doctor stationed at C.B.Z. Djakarta as Chirurgie (surgeon), then was transferred to Banyumas then to Purworejo, C.B.Z. Semarang as Chirurgie (surgeon) and in Madiun until 1902. While undergoing his career as a Javanese Doctor, Radjiman got an offer to continue his studies, then he returned to the Netherlands and studied at the University of Amsterdam in the health section of 1910 then studied in Berlin in the year 1911 and studied again in Amsterdam in 1919-1920 then also studied in Paris in 1930[12].

Radjiman's romance did not go very well, as explained in the Chronicle of Wedyadiningratan that when Radjiman was on duty in Madiun, he had to divorce his wife. Radjiman's condition, which was considered quite alarming, encouraged the spirit to pursue psychology. Before becoming a royal doctor in Surakarta, Radjiman devoted himself to be a doctor at the Mental Hospital in Lawang (Malang). During his ten years of service at the Mental Hospital, while studying theosophy of esoteric science, he also became a well-known person in the community. On August 26, 1906 he was officially appointed as a royal doctor in Surakarta as Mantri Nayaka Luar, Panumping Regency group, under the name of Mas Ngabehi Doctor Mangunhusada and received a monthly salary of $f 50$, plus a five Jung from sawah ganduhan (from the paddy field he can earn a profit of eight hundred every half year) [8]. After his tenure was sufficient and many of his services, later Radjiman was appointed as the doctor regent by the name of Raden Tumenggung Wedyadiningratan until he was called kanjeng and was awarded various kinds of awards. From his concern, being diligent, patient, wise, careful, friendly and easy to get along with others, those brought Radjiman known among the wider community.

\subsection{Analysis of Theosophical Thought dr. K.R.T Radjiman Wediodiningrat to Civic Intelligence Understanding}

The existence of the theosophical movement in Indonesia concerning realizing civic intelligence was the opening of several teaching schools for pribumi, namely Arjuna school or Ardjoena Scholen[9]. Teaching given at Arjuna school is basically the same as other schools established for pribumi but in teaching at Arjuna school also includes teaching about nationalism which is training to educate students to be people who love their homeland and have good morals. The learning is constructive, informing civic intelligence in every student[17]. Agree with Media Zainul Bahri that theosophy has presented an educational model that appreciates differences of religion and culture, which is currently known as "multicultural education"[18]. 
Radjiman is a person who was asked to be a bridge for national figures and the colonial government. Although Radjiman studied theosophy and socialized a lot with Europeans, it did not make Radjiman forget his identity as a Javanese and remain selfish and dissatisfied with his findings. His goal is to escape from colonialism, and his struggle is still high, with friends from STOVIA. Feelings of the same fate and continuity were the basis of their struggle. Indonesia is Pancasila, besides that theosophy also contributes considerably in terms of uniting groups in the Indonesian State and provides away in terms of supporting political efforts to facilitate relations between nations and countries around the world[19].

The thoughts of dr inspired Radjiman's ideas. Wahidin Sudirohoesodo as well as the teachings of theosophy to produce heroic values that can be emulated, which are in their achievements to realize the Indonesian nation that has civic intelligence. Civic Intelligence is one of the essential points that must be owned by every citizen in any country, to be able to compete with others. Civic Intelligence is ready to be a control tool for the creation of a harmonious national and State life. His deepening of theosophy made Radjiman have civic intelligence, the following explanation:

1. Intellectual knowledge

When Radjiman was assigned to become the head of BPUPK[20] his mental experience was visible, which was demonstrated the ability to process various kinds of information, then his ability to communicate with anyone, the ability to establish cooperation and make decisions. Besides, his experience in studying abroad and his involvement in movement organizations such as Boedi Oetomo, besides being the chairman of Radjiman was also active as the editorial team at Timboel magazine[21]. In the magazine, the Radjiman thought was outlined as a form of fighting for Indonesian independence. In today's digital era, the ability to process various kinds of information becomes an essential skill that must be possessed by young people because it is selective and not easily provoked by fake news.

2. Emotional intelligence

Not all doctors have thoughts like Radjiman; Radjiman's emotional intelligence is evident when he runs his profession as a doctor. When all people are reluctant to be assigned to handle the bubonic plague in Ngawi, they are happy to be assigned there[8]. Besides, in his career, when he meets an incapable patient, he is delighted to treat his patients even without payment. The attitude of helping others shown by Radjiman can be categorized as an expression of altruism (helping sincerely) [22]. Thus it can be said that altruism is a manifestation of human values, which is certainly in line with the objectives of the theosophical association. For the people of theosophy of humanity is an essential point in creating a harmonious life in the community association. Individual attitudes which currently infect various groups of people, especially people who live in cities do not reflect the position of the first Indonesian nation, because as we know that this country was formed based on the principle of gotong royong.

3. Spiritual intelligence

Although not a devout follower of religion, Radjiman never hurt others. He always tried to help others, and he ever tried to make solid truth values as a guide in living life. His entry into the Theosophical organization and pursuing the esoteric field[8] shows that his desire for spiritual matters is so great.

4. Moral intelligence

As a person who studied Dutch and socialized with many Europeans did not make Radjiman an arrogant figure, who forgot his identity. In carrying out his every job, he always is tolerant, honest and patient. For example, in every state event meeting, even 
though he was wearing a suit, Radjiman always wore a blangkon and jarik, it was done to show that he was Javanese. Radjiman's attitude of tolerance is also always shown through his writings published in newspapers and magazines[21].

Based on this analysis illustrates how the influence of theosophy on Radjiman's thinking. Radjiman's personality formation can be illustrated through the concept of Alferd Adler in personality psychology theory, namely the following are two basic methods of striving towards the ultimate goal according to Alferd Adler who is a picture of the elite in ancient times and the leaders of fighters (especially Radjiman):
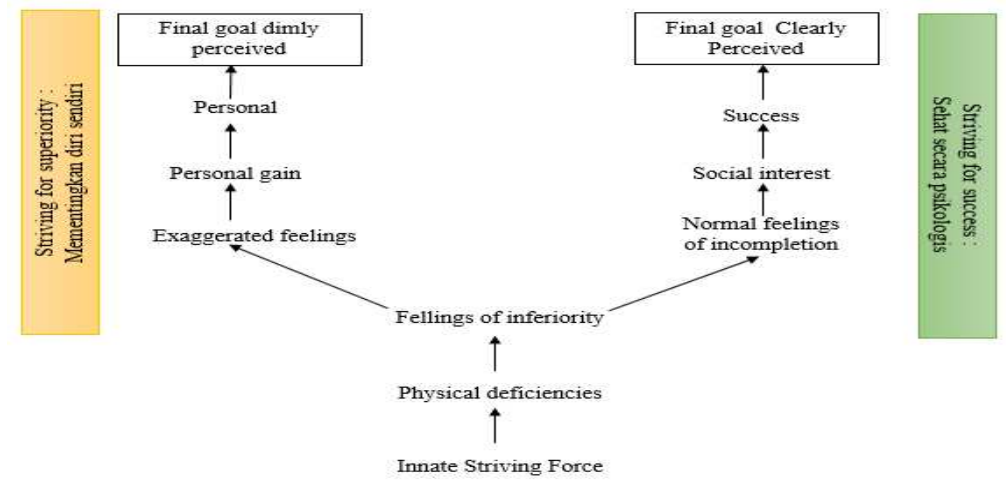

If you see this picture, the thinking and character of Radjiman in realizing Civic Intelligence can be categorized into striving for success because when Radjiman achieves success, it does not make him satisfied and that success is used for social purposes rather than for personal gain. The theory used to express the primary motivations that drive other motivations. Adler makes awareness a centre of personality, that is, humans are conscious beings, they are always aware of the reasons for their behaviour and can plan and guide their actions with full awareness of their meaning for their realization[23]. So, Radjiman's abilities and success through such a tremendous and concerted struggle did not make Radjiman complacent and selfish, through his profession as a doctor, Radjiman sincerely helped others and in his association became a sympathetic figure, being able to collaborate intellectual intelligence, emotional intelligence, intelligence spiritual and moral intelligence. There is no doubt, besides being smart and easy-going, Radjiman was also one of the people that was respected by both figures in the country and Europeans. So, civic intelligence makes Radjiman a person of strong character and respect to many people [24].

\section{Conclusion}

Civic Intelligence becomes an important ability that must be possessed by everyone. In Indonesia, civic intelligence is only facilitated through Citizenship Education lessons in schools, but history learning should also lead to the formation of civic intelligence. Through a short biography, dr. K.R.T. Radjiman Wedyodiningrat, it can be seen how his life story can inspire and serve as an afterthought for young people in this time and the future. Extraordinary thought and devotion to the homeland and the nation. The theosophical movement, which in the minds of the public, contains elements of pros and cons can be explored and applied well by Radjiman. Theosophy becomes an essential part of Radjiman's life journey; theosophy is a 
filler of the emptiness of his soul. For him, there is no knowledge that is not useful; it just goes back to the user, then the good and evil depend on each other's perceptions.

\section{References}

[1] D. Schuler, "Cultivating society's civic intelligence: Patterns for a new world brain," Information Communication and Society, vol. 4, no. 2, 2001.

[2] D. Schuler, "Pieces of Civic Intelligence: Towards a capacities framework," E-Learning and Digital Media, vol. 11, no. 5, 2014

[3] K. Nurmalina and Syaifullah, Memahami Pendidikan Kewarganegaraan. Bandung: Laboratorium PKn UPI, 2008.

[4] A. J. Fenton, "Faith, Intolerance, Violence \& Bigotry Legal \& Constitutional Issues of Freedom of Religion in Indonesia," Journal of Indonesian Islam, vol. 10, no. 2, 2016.

[5] A. Kanas, P. Scheepers, and C. Sterkens, "Interreligious Contact, Perceived Group Threat, \& Perceived Discrimination: Predicting Negative Attitudes among Religious Minorities \& Majorities in Indonesia," Social Psychology Quarterly, vol. 78, no. 2, 2015.

[6] K. Azali, "Fake News and Increased Persecution in Indonesia," ISEAS Perspective, vol. 1, no. 61, 2017.

[7] H. Djanggih, "The Phenomenon of Cyber Crimes Which Impact Children As Victims in Indonesia," Yuridika, vol. 33, no. 2, 2018.

[8] Dutadilaga, Babad Wedyadiningratan. Jakarta: Departemen of Education and Culture, 1980.

[9] I. P. Nugraha, Teosofi, Nasionalisme \& Elite Modern Indonesia. Jakarta: Komunitas Bambu, 2011.

[10] S. Soejatno, "Sambutan Pembukaan Konggres Perwathin Ke X di Bandung Tanggal 20 April 1973," Berita P.B. Perwathin, Jakarta, 1973.

[11] L. Gottschalkm, Mengerti Sejarah. Jakarta: Universitas Indonesia Press, 1986.

[12] Gunseikanbu, Orang Indonesia yang Terkemuka di Jawa. Yogyakarta: Gajah Mada University Press, 1986

[13] S. Ja'far, "Struktur Kepribadian Manusia Perspektif Psikologi dan Filsafat," Psympatic Journal Ilmiah Psikologi, vol. 2, no. 2, 2015.

[14] R. Gunawan, "Modern Elite Society and National Movement," International Journal of History Education, vol. XII, no. 1, 2011.

[15] A. Etek, M. A.M., and A. B.R., Kelah Sang Demang Jahja Datoek Kajo: Pidato Otokritik di Volkstraad 1927-1939. Yogyakarta: Lkis Pelangi Aksara, 2008.

[16] S. Mangunwidodo, Dr.K.R.T. Radjiman Wediodiningrat: Perjalanan Seorang Putra Bangsa 1879-1952. Jakarta: Yayasan dr. K.R.T. Radjiman Wediodiningrat, 1994.

[17] M. C. Ricklefs, A History of Modern Indonesia. London: The Macmillan Press, 1982.

[18] M. Z. Bahri, "Indonesian Theosophical Society (1900-40) and the Idea of Religious Pluralism," Southeast Asian Studies, vol. 6, no. 1, 2017.

[19] R. S. Ramuwisit, Theosofi. Semarang: N.V. Wijasa, 1955.

[20] M. Yamin, Risalah Sidang BPUPKI dan PPKI. Jakarta: Sekretariat Negara Republik Indonesia, 1992.

[21] "Godsdienstige Bladen," Overzicht van de Inlandsche en Maleisch-Chineesche Pers, no. Zaterdag 12 Maart, 1927.

[22] O. Curry, S. G. B. Roberts, and R. I. M. Dunbar, "Altruism in social networks: Evidence for a 'kinship premium,"' British Journal of Psychology, vol. 104, no. 2, 2012.

[23] A. Purnama, "Struggle of Mark Watney for Life in The Martian by Andy Weir (2014): An Individual Psychological Perspective," Muhammadiyah Surakarta University, 2018.

[24] K. Saddhono and S. Supeni. "The role of dutch colonialism in the political life of Mataram dynasty: A case study of the manuscript of Babad Tanah Jawi." Asian Soc. Sci. vol. 10 no.15 pp. $1-7,2014$ 
